\title{
Pyometra in a Cat: A Clinical Case Report
}

\author{
Tanjila Hasan ${ }^{1}$, Md. Monir Hossan², Nazifa Tahsin ${ }^{3}$, Md. Afzal Hossain ${ }^{4}$ and AHM Musleh Uddin ${ }^{5 *}$ \\ ${ }^{1}$ Department of Medicine and Surgery, Faculty of Veterinary Medicine, Chattogram Veterinary and Animal Sciences University, \\ Bangladesh
}

${ }^{2}$ Upazilla Livestock Officer, Department of Livestock Services, Bangladesh

${ }^{3}$ Veterinary Officer, Palli Karma Shohayok Foundation (PKSF), Bangladesh

${ }^{4}$ Veterinary Surgeon, Teaching and Training Pet Hospital, Bangladesh

${ }^{5}$ Department of Surgery and Theriogenology, Faculty of Veterinary, Animal and Biomedical Sciences, Sylhet Agricultural University, Bangladesh

*Corresponding author: AHM Musleh Uddin, Assistant Professor, Department of Surgery and Theriogenology, Faculty of Veterinary,

Animal and Biomedical Sciences, Sylhet Agricultural University, Sylhet 3100, Bangladesh

\section{ARTICLE INFO}

Received: 蔧 July 28, 2021

Published: August 06, 2021

Citation: Tanjila Hasan, Md. Monir Hossan, Nazifa Tahsin, Md. Afzal Hossain, AHM Musleh Uddin. Pyometra in a Cat: A Clinical Case Report. A Review of Literature. Biomed J Sci \& Tech Res 37(5)-2021. BJSTR. MS.ID.006068.

\begin{abstract}
Pyometra is one of the most common reproductive problem in cat. An eleven-yearold native cat was admitted to Teaching and Training Pet Hospital and Research Centre, Chittagong Veterinary and Animal Sciences University, Bangladesh, with history of anorexia and chronic emaciation. At first, general physical examination was done then special examination was performed. On abdominal ballottement, uterus felt harder and enlarged than normal. Then ultrasonography examination was done where found multiple tubulars, radio-opaque fluid filled structures from caudal to mid abdomen. Blood analysis showed that the level of AST, ALT, urea, creatinin increased, and PCV and $\mathrm{Hb} \%$ decreased. All the findings confirmed that cat had suffering from pyometra. After confirmation, it was decided to do ovariohysterectomy under general anesthesia. The suture was removed after fourteen days. The cat had a complete recovery without any complication.
\end{abstract}

Keywords: Cat; Pyometra; Ultrasonography; Blood Analysis; Ovariohysterectomy

\section{Introduction}

Pyometra is an acute or chronic suppurative inflammation of the uterus. It is characterized by endometrial hyperplasia with cystic dilation of endometrial glands and accumulation of a neutrophil-rich exudate in the uterine lumen. The incidence of feline pyometra is still not well documented and probably underestimated because queens often don't present with clinical signs [1]. No prevalence data for pyometra have so far been described in cats, but observations of most veterinarians are that the disease is observed less commonly than in dogs. The most common clinical finding in case of $75 \%$ of pyometra cases is mucopurrulent to hemorrhagic vaginal discharge [2]. The clinical presentation of pyometra is similar in cats and dogs. In 'open-cervix pyometra' a blood stained; purulent vaginal discharge may be the only clinical sign. Animals with 'closed-cervix pyometra' may not show any vaginal discharge and are more commonly systemically ill because resorption of bacterial toxins from the uterine lumen into the circulation can result in endotoxaemia. Bacteremia may also occur. Non-specific clinical signs such as anorexia, vomiting, lethargy, loss of weight and unkempt appearance can also be observed [3]. Polyuria and polydypsia do not occur as often as in dogs. They were reported only in $9 \%$ of the cases [4].

Abdominal ultrasound is the most important diagnostic tool in a pyometra case. The uterine horns typically appear distended with hypo-/ to hyperechoic fluid with or without flocculation. The uterine wall often appears thickened with irregular edges and small hypoechoic areas consistent with cystic changes of the endometrial glands. The pyometra can be diffuse or segmental. Cytology of the uterine or vaginal discharge is likely to reveal degenerative 
neutrophils and phagocytized bacteria. Leukopenia can be present in around 5\% of the cases [4]. Treatment includes correction of fluid deficits, proper administration of antibiotics against bacterial organisms and removal of infected uterine contents. The other management includes surgical removal of ovary and uterus (ovariohysterectomy) or use of by PGF2 $\alpha$ [3]. The decision to try medical or surgical therapy is based on the physical status and breeding capacity of the queen.

However, some complications may develop after ovariohysterectomy (OHE), such as ovarian remnant syndrome (ORS). This syndrome may develop because of the failure to totally remove both ovaries (most commonly the right ovary) at OHE, or the presence of a partial or complete separation of a portion of normal ovary (the fragment may be located near the ovary or in the broad ligament) that is not detected at OHE. In some cases, uterine stump pyometra may occur because of ovarian remnants and this situation may be fatal in affected queens. Worldwide, fatal complications occur as a result of surgical errors in routine OHE. In this article, we report and discuss the procedure and importance of ORS in a queen.

\section{Materials and Methods}

\section{History and Clinical Examination}

An eleven years old local breed cat was admitted to Teaching and Training Pet Hospital and Research Centre, Chittagong Veterinary and Animal Sciences University, Bangladesh, with history of anorexia, chronic emaciation. At first, general physical examination was done, then special examination was done. On physical examination, body temperature found $101^{\circ} \mathrm{C}$, heart rate 174 beats per minute and respiratory rate 42 breaths per minute.

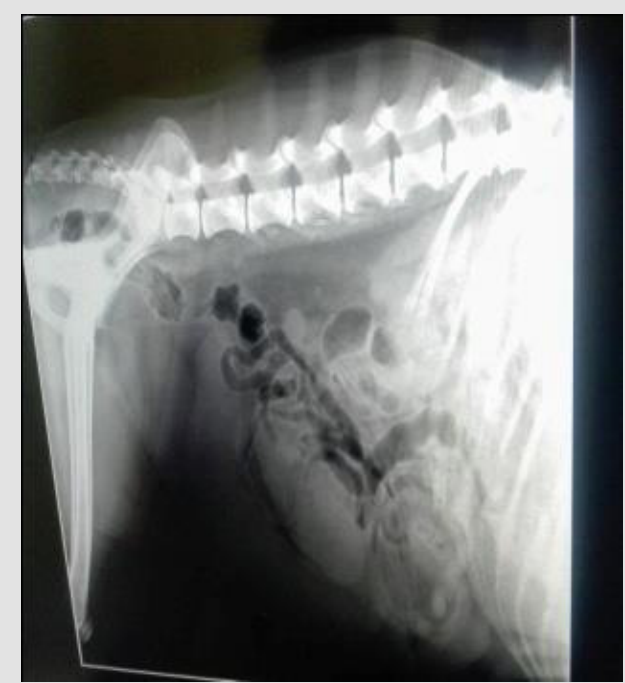

Figure 1: Multiple tubular, radio-opaque fluid filled structures

On abdominal ballottement the uterus felt harder and enlarged than normal. Lateral radiograph revealed multiple tubular, radio- opaque fluid filled structures from caudal to mid abdomen (Figure 1). The structures appeared distinct and separate from the intestinal loops. Ultrasonography was performed using a B mode real-time $5 \mathrm{MHz}$ linear transducer. The finding of abdominal ultrasound was found multiple anechoic fluid filled area without foculation (Figure 2). Then blood sample was collected for doing routine examination and serum analysis.

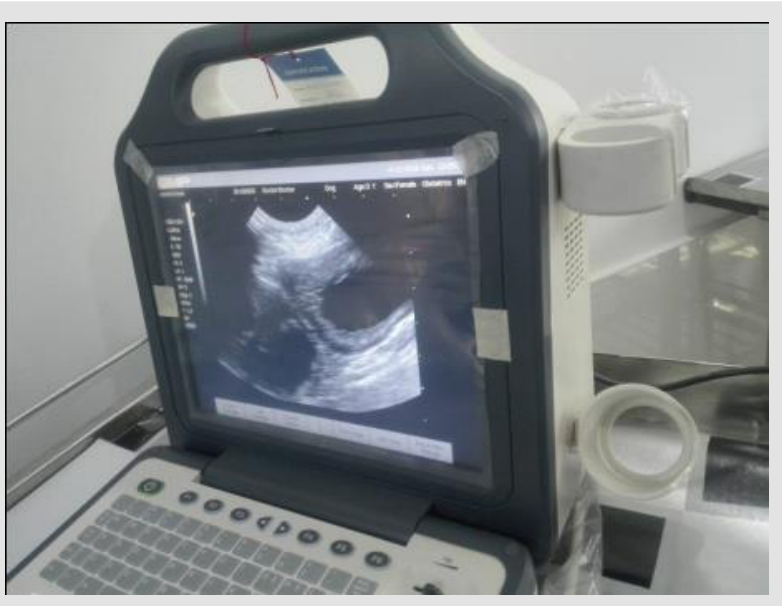

Figure 2: Multiple anechoic fluid filled pocket.

\section{Surgical Management}

Restraining and Anesthesia: Firstly, the cat was being held on its side with its back against the handler, while the handler grasps the front and back legs, with a forearm across the cat neck. As premedication agent atropine sulphate was administered (Injection Atropine $^{\circledR}$, Techno drug, Bangladesh, $0.04 \mathrm{mg} / \mathrm{kg}$ body weight intramuscularly) and as muscle relaxant xylazine hydrochloride (Injection xylazine ${ }^{\circledR}$, Indian Immunologicals Ltd, India, 1mg/ kg BW intramuscularly) administered. Again, as a general anesthesia ketamine hydrochloride (G-ketamine ${ }^{\circledR}$, Gonoshasthaya Pharmaceuticals Ltd., Bangladesh, $15 \mathrm{mg} / \mathrm{Kg}$ body weight intravenously) was administered. The maintenance anesthetic dose was given half of the initial dose during the surgery. Preparation of surgical area was carried out after shaving and removing hairs. $70 \%$ alcohol scrubbed onto the skin around the surgery area, the area is then covered until surgery, since nothing must touch it once it is cleaned.

Surgical Procedure: The cat was being laid on her back (Figure 3) and a sterile drapper was placed over her. Close monitoring of temperature, blood pressure, heart rate, gum color, pulse strength and depth of anesthesia was done. An incision was made in the middle of the underside along the length of the abdomen. After exposing the abdomen by laparotomy, the uterine and ovarian blood vessels were properly secured and the ovaries, uterine horns and uterus were completely removed. The abdominal wall was closed with catgut (size: 1-0). The skin was then closed with cross-mattress suture pattern using silk. The sutured wound was 
covered with the benzoin seal. During the entire operative period, $5 \%$ dextrose saline was intravenously infused.

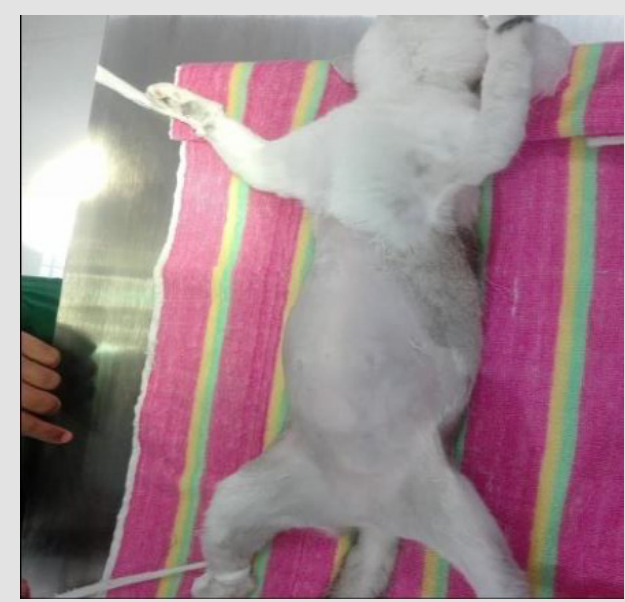

Figure 3: Lying the cat at dorsal recumbent position.

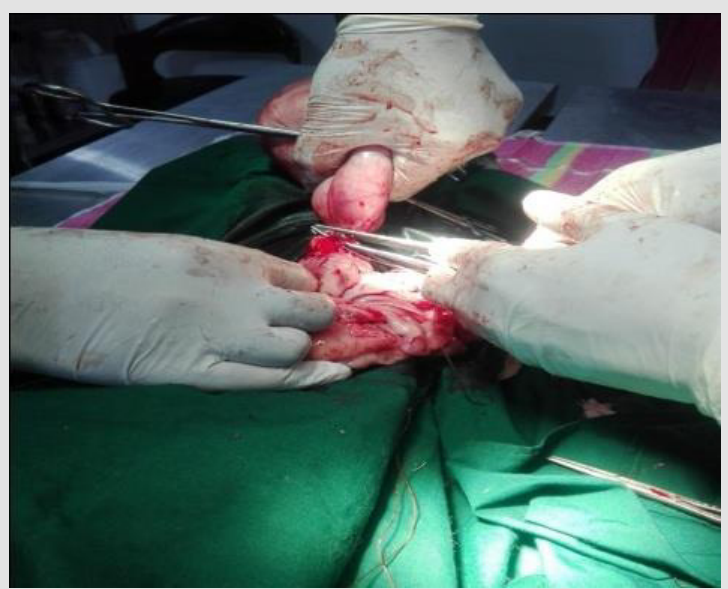

Figure 4: Ligating the uterus at the base of the uterine body.

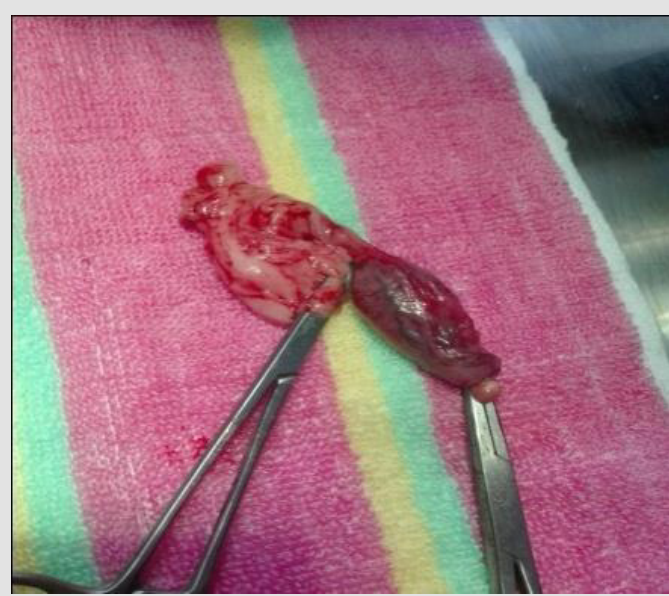

Figure 5: Removal of ovaries.
Post-Operative Care: After surgery, antibiotic ceftriaxone $@ 20 \mathrm{mg} / \mathrm{Kg}$ body weight (Injection Triject vet $1 \mathrm{gm}^{\circledR}, \mathrm{SK}+\mathrm{F}$ Pharmaceuticals, Bangladesh) was administered intramuscularly daily for 7 days. Antihistaminic chlorpheneramine maleate $@ 1 \mathrm{mg} / \mathrm{Kg}$ body weight (Injection Astavet ${ }^{\circledR}$, Acme Laboratories Ltd., Bangladesh) was administered intramuscularly daily for 7 days. Analgesic (Injection meloxicam @ 040 mg/Kg body weight and Injection Melvet ${ }^{\circledR}$, Acme Laboratories Ltd., Bangladesh) was administered subcutaneously daily for 5 days for pain management. The patient was kept in clean squeeze cage and observed for 7 days. No complication was noted, and the bitch recovered uneventfully. On the $14^{\text {th }}$ day, the suture was removed, and it was noticed that the surgical site was healed completely (Figures 4-9).

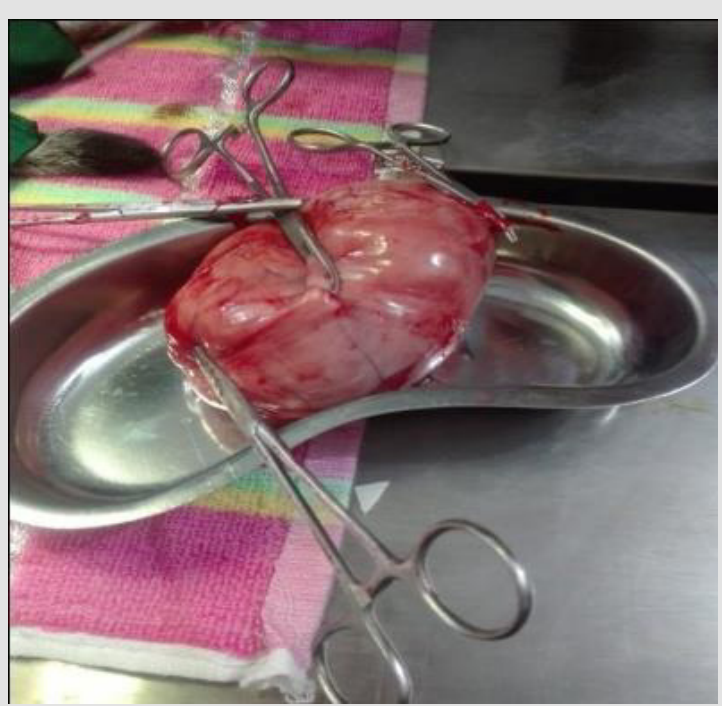

Figure 6: Removal of uterus.

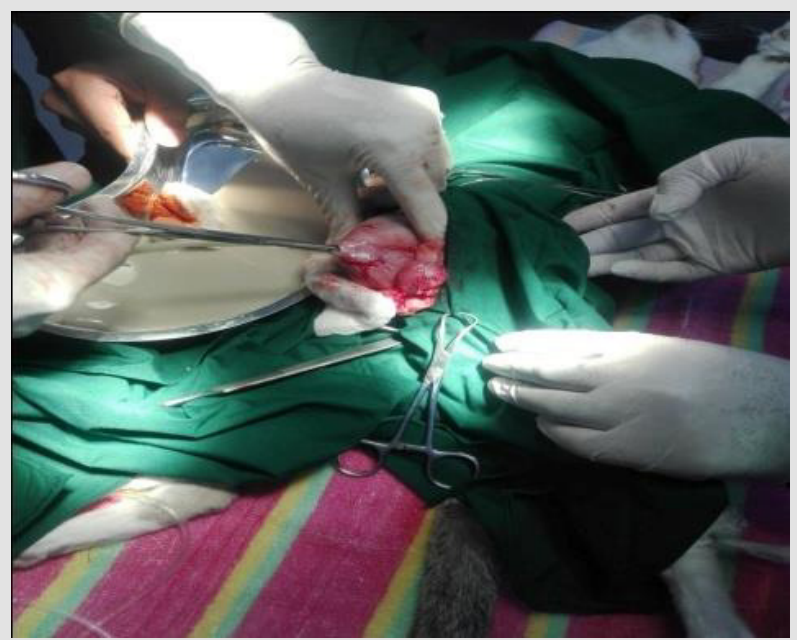

Figure 7: Release of pus from uterus. 


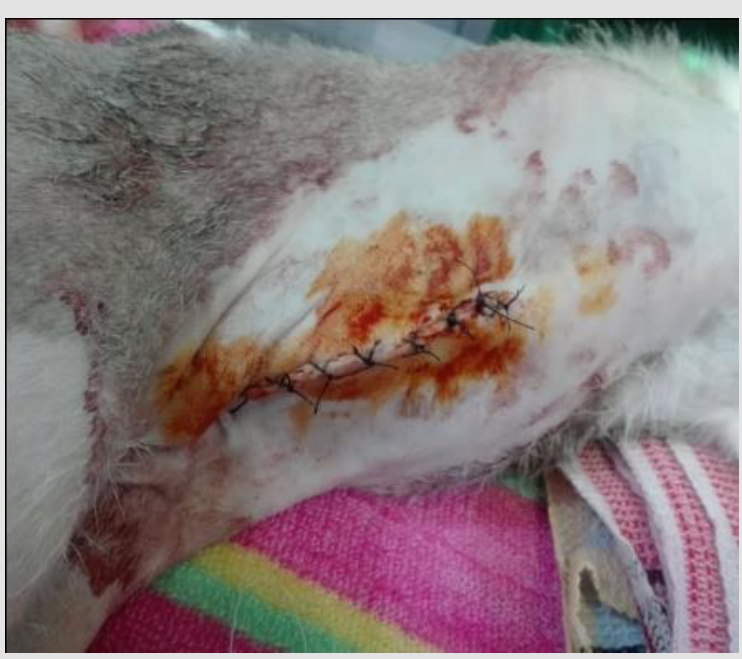

Figure 8: Application of benzoin seal.

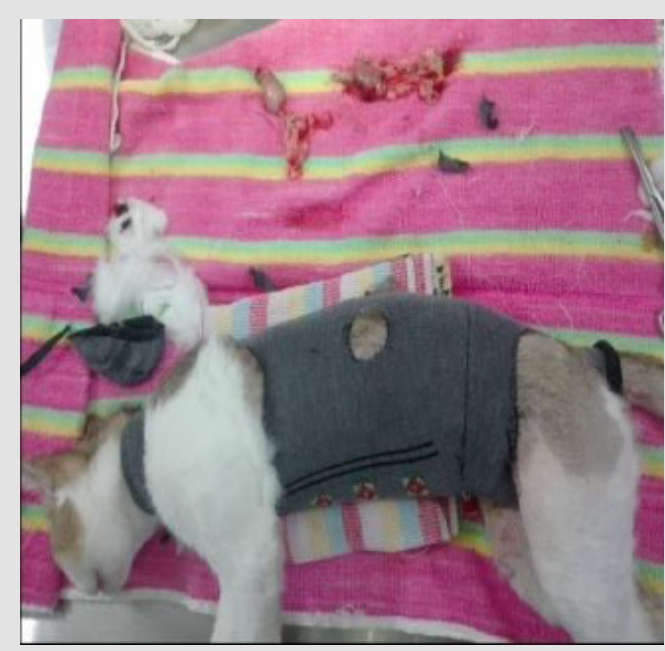

Figure 9: Cat after surgery.

\section{Results and Discussion}

Pyometra is a uterine inflammatory disorder characterized by cystic endometrial hyperplasia [5]. Potter et al. Potter et al. [6] concluded that the prevalence of pyometra in cats increases with age in sexually intact female cats and mainly after parturition, while Agudelo, [7] suggested that the disease is common in queens older than three years and in other queens older than five years with no relationship to the number of parturitions, these close to findings were reported in this case. Hagman et al. [8] found comparatively higher prevalence of pyometra in Bengal cat which is almost similar to this study. Pyometra is a disease of the middle-aged or older animal which was also stated by Brady et al. It could be speculated whether this increase is related to degenerative changes in the uterus or other conditions such as ovarian pathologies or uterine neoplasia that more often affect older animals and may predispose for developing pyometra. But it has been described also in younger cats [9-11].

Table 1: Hematological and biochemical analysis of pyometric cat.

\begin{tabular}{|c|c|c|}
\hline $\begin{array}{c}\text { Hematological } \\
\text { parameters }\end{array}$ & Results & Reference value \\
\hline Total RBC & 4 & $5-10$ \\
\hline Total WBC & 3.5 & $5.5-19.5$ \\
\hline PCV (\%) & 19 & $29-45$ \\
\hline Hb (\%) & 4.5 & $9.8-15.4$ \\
\hline MCV (fl) & 59 & $41-54$ \\
\hline MCH (pg) & 18 & $13-17$ \\
\hline MCHC (\%) & 37 & $31-36$ \\
\hline Neutrophil (\%) & 80 & $35-75$ \\
\hline Lymphocyte (\%) & 20 & $27-36$ \\
\hline Monocyte (\%) & 2 & $0-5$ \\
\hline Basophil & 0 & $0-1$ \\
\hline Eosinophil (\%) & 1 & $0-4$ \\
\hline & Biochemical Parameters \\
\hline AST & 36 & $7-38$ \\
\hline ALT & 99 & $25-97$ \\
\hline Urea & 41 & $19-34$ \\
\hline Creatinine & 3.8 & $0.9-2.2$ \\
\hline
\end{tabular}

Present study before treatment the hemoglobin level of cat was decreased indicating anemia which agrees with the previous reports $[12,13]$. This might be due to loss of red blood cells by diapedesis into uterine lumen apart from depressed feed intake and impaired erythropoiesis under toxemic condition in severely affected cases [14]. The PCV level was decreased in the bitches indicating a mild normocytic, normochromic philia might be due to and regenerative type of anemia [15]. According to Greene et al. [16] total erythrocyte count before treatment was decreased in the bitches affected with pyometra indicating anemia which is similar to this study. It might be associated with the toxic depression of the bone marrow whereas severe non-regenerative, microcytic, hypochromic anemia accompanied by extremely high white blood cell levels might be indicative of a concurrent blood loss possibly by diapedesis into luminal pus and due to shortened life span of circulating erythrocytes associated with iron deficiency [17]. Different degree of leucocytosis was observed in bitches affected with pyometra which is consistent to this study. It might be due to severity of the inflammation varying between animals.

In the present study, absolute neutrophilia, lymphopenia, monocytosis with normal eosinophil count was the most consistent finding among the bitches affected with pyometra. Neutrophilia with regenerative shift to the left might be due to retention of purulent exudates in the uterus which exerts a chemotactic 
effect on neutrophils resulting into accelerated granulopoiesis and lymphopenia might be due to severe stress and elevated monocyte count might be due to chronic suppurative process [12]. Neutrophilia is a typical feature in hematology of bitches affected with pyometra [18] which might be due to influence of toxins in pyometra [19]. The ovariohysterectomy is the useful treatment of pyometra. Potter et al. [6] recorded that $61 \%$ of affected cats were spayed or died because of complications relating to reproductive tract disease. The case fatality for pyometra overall was $5.6 \%$. In dogs it is reported to be $3 \%$ to $4 \%$ [20]. The reason for the higher fatality rate in cats is not known, but one theory could be that this species is less sensitive to endotoxin, or not as prone to show clinical signs unless they develop sepsis [21].

Pyometra can cause liver and kidney function changes (Nak et al. 2001). Occasionally, in this study ALT level moderately increased which support the finding of Nak [22]. Because of septicemia hepatocellular damage were happened resulting diminished hepatic circulation and cellular hypoxia in the dehydrated cats. In this study, decreased ALT result can explain by a process of inhibition of liver enzyme synthesis or possible hepatic membrane damage. Renal dysfunction may develop secondary related to bacterial endotoxin to pyometra. In this case, blood urea nitrogen and creatinine concentration increased it might be due to dehydration [23-27]. A high creatinine concentration was determined in $12 \%$ of a group of cats with pyometra Kenney et al. [28].

In this study, ovariohysterectomy was performed under general anesthesia using xylazine hydrochloride and ketamine hydrochloride which is almost similar to study of Deniz et al. [28] The causes of postoperative wound dehiscence include rough handling and tearing of tissues during surgery, improper selection of the suture material, inefficient suturing, infection, hematoma or seroma formation, failure to obliterate dead space and training of the animal. In such cases, debriment and fresh coaptation of the wound is indicated [29].

\section{Funding}

No funding.

\section{Conflict of Interests}

The authors declare that they have no conflict of interest.

\section{References}

1. Brady CA, Otto CM, Van WinkleTJ, King LG (2000) Severe sepsis in cats: 29 cases (1986-1998). Journal of the American Veterinary Medical Association 217(4): 531-535.

2. Kenney KJ, Matthiesen DT, Brown NO, Bradley RL (1987) Pyometra in cats: 183 cases (1979-1984). Journal of the American Veterinary Medical Association 191(9): 1130-1132.
3. Nak D, Misirlioglu D, Nak Y, Keskin A (2005) Clinical laboratory findings, vaginal cytology and pathology in a controlled study of pyometra in cats. Australian Veterinary Practitioner 35(1): 10-14.

4. Verstegen J, Incline K (2006) The Mucometra-Pyometra complex in the queen. In North American Veterinary Community Conference :1277.

5. Lucas SS, Lima de Oliveira AL, Wallau JE (2000) Pyometra in Dogs and Cats: Review of 103 cases. Revista da Faculdade de Zootecnia, Veterinaria e Agronomia Uruguaiana 7: 99-103.

6. Harvey M (1998) Alterations in the non-pregnant female. In: Manual of Small Animal Reproduction \& Neonatology, $1^{\text {st }}$ edition, Edited by Simpson GM, England GC and Harvey M. British Small Animal Veterinary Association (BSAVA), Gloucestershire pp: 47-68.

7. Jhonson CA (1994) Female reproduction and disorders of the female reproductive tract. In: The Cat. Diseases and Clinical Management, vol. $2,2^{\text {nd }}$ Edition, Edited by R Sherding. Churchill Livingstone, New Yor, pp: 1855-1876.

8. Johnston SD, Root MV, Olson PN (2001) Canine and Feline Theriogenology, lst edition, 2001. W.B. Saunders Company. Philadelphia. pp. 396-405 and pp: 447-471.

9. Potter, Hancock DH, Gallina AM (1991) Clinical and pathologic features of endometrial hyperplasia, pyometra, and endometritis in cats: 79 cases (1980-1985). Journal of American Veterinary Medicine Association 198: 1427-1431.

10. Agudelo CF (2005) Cystic Endometrial Hyperplasia-Pyometra Complex in cats, a review. Veterinary Quarterly 27(4): 173-183.

11. Hagman R, Kindahl H, Lagerstedt AS (2006) Pyometra in bitches induces elevated plasma endotoxin and prostaglandin F á metabolite levels, Acta Veterinaria Scandinavica 47: 55-68.

12. Miller MA, Ramos-Vara JA, Dickerson MF, Johnson GC, Pace LW, et al. (2003) Uterine neoplasia in 13 cats. Journal of Veterinary Diagnostic Invesigationt 15: 515-522.

13. Sontas H, Erdogan Ö, Apaydin Enginler SÖ, Yilmaz ÖT, Sennazli G, et al. (2013) Endometrial adenocarcinoma in two young queens. Journal of Small Animal Practice 54: 156-159.

14. Payan-Carreira R, Saraiva A, Santos T, Vilhena H, Sousa A, et al. (2013) Feline endometrial adenocarcinoma in females < 1 year old: a description of four cases. Reprodion of Domestic Animal.

15. Singh S, Dadhich H, Sharma GD (2006) Haemato-biochemical studies in cystic endometrial hyperplasia pyometra complex in canine, Indian Journal of Veterinary Pathology 30: 46-48.

16. Nath K, Tiwari SK, Kalim O (2009) Physiological and haematological changes in bitches with pyometra, Indian Veterinary Journal 86: 734 736.

17. Dabhi DM, Dhami AJ, Parikh PV, Patil DB (2009) Comparative evaluation of haematological parameters in healthy and pyometra affected bitches, Indian Journal of Animal Reproduction 30:70-72.

18. Nelson RW, Feldman EC (1986) Pyometra. Veterinary Clinics of North America: Small Animal Practice 16: 561-576.

19. Greene CE, Miller MA, Brown CA (1998) Pyometra in bitches induces elevated plasma endotoxin and cystic endometrial hyperplasia complex. Infectious Diseases of Dog and Cat. Philadelphia, London: 623-626.

20.Schepper JD, Stock JVD, Capiau E (1987) Anaemia haematological changes in bitches with pyometra Journal of Small Animal Practice 28: 137-145.

21. Pande N, Prabhakar S, Gandotra VK, Honparkhe M, Nanda AS (2006) Efficacy of different techniques for diagnosis of pyometra in female dogs, Indian Journal of Animal Reproduction 27: 31-33. 
22. Hagman R, Kindahl H, Fransson BA, Bergström A, Holst BS, et al. (2006) Differentiation between pyometra and cystic endometrial hyperplasia/ mucometra in bitches by prostaglandin F2-alpha.

23. Egenvall A, Hagman R, Bonnett BN, Hedhammar A, Olson P, Lagerstedt AS (2001) Breed risk of pyometra in insured dogs in Sweden. Journal of Veterinary Internal Medicine 15:530-538.

24. Van Miert AS, Frens J (1968) The reaction of different animal species to bacterial pyrogens. Zentralbl Veterinarmed A 15: 532-543.

25. Nak, D (1999) Kedi vekopeklderde pyometranin fizyopatolojisi, tanisi ve prostaglandinlerle sagitimi, Y Y Ü Sagi Bil Enst Derg 5: 79.

ISSN: 2574-1241

DOI: 10.26717/BJSTR.2021.37.006068

AHM Musleh Uddin. Biomed J Sci \& Tech Res

(c) (P) This work is licensed under Creative

Submission Link: https://biomedres.us/submit-manuscript.php
26. Deniz N, Deniz M, Yavuz N, Abdülkadir K (2005) Cytology and pathology in a controlled study of pyometra in cats. Australian Veterinary Practice 35 (1): 10-14.

27. Singh, H (1993) Wound healing and tissue repair. Ruminant Surgery (Eds) Tyagi RPS and Singh J. 1st edn. pp: 59-60.

28. DOW C (1959) The cystic hyperplasia-pyometra complex in the bitch. Journal of comparative pathology 69: 237-250.

29. Johnston SD, Root-Kustritz MV and Olson PN (2001) Canine and Feline Theriogenology. Philadelphia: WB Saunders, pp. 389-474.

$\begin{array}{ll}\text { BIOMEDICAL } & \text { Assets of Publishing with us } \\ \text { RESEARCHES } & \text { - Global archiving of articles } \\ \text { - Immediate, unrestricted online access }\end{array}$

